\title{
ADEQUATE LYMPHADENECTOMY FOR COLORECTAL CANCER: A COMPARATIVE ANALYSIS BETWEEN OPEN AND LAPAROSCOPIC SURGERY
}

\author{
Linfadenectomia adequada para o câncer colorretal: análise comparativa entre procedimento cirúrgico aberto e laparoscópico
}

Vilson Leite BATISTA ${ }^{1}$, Antonio Carlos Ribeiro Garrido IGLESIAS ${ }^{1}$, Fernando Athayde Veloso MADUREIRA ${ }^{1}$, Anke BERGMANN ${ }^{2}$, Rachel Perez DUARTE ${ }^{1}$, Bárbara Ferreira Saraiva da FONSECA ${ }^{1}$

From the ${ }^{1}$ Universidade Federal do Estado do Rio de Janeiro - UNIRIO and 'Instituto Nacional do Câncer - INCA (Federal University of Rio de Janeiro State and Cancer National Institute - INCA), Rio de Janeiro, RJ, Brazil.

HEADINGS - Colorectal surgery. Lymph node removal. Video-assisted surgery.
ABSTRACT - Background: In the surgical treatment of colorectal cancer, a lymphadenectomy is considered adequate when at least 12 lymph nodes are removed. Aim: To evaluate whether videolaparoscopic surgery positively affects the rates of adequate lymphadenectomy. Methods: An observational study was conducted with patients undergoing either open or videolaparoscopic surgery for colorectal cancer between 2008 and 2013. The following variables were collected: gender, age, tumor site, histology, degree of differentiation, tumor stage, number of lymph nodes removed, and number of lymph nodes affected by the disease. Results: A total of 62 patients with colorectal cancer were included; 42 (67.7\%) received open surgery, and 20 (32.3\%) laparoscopic surgery. Regarding lymphadenectomy, a mean of 13 lymph nodes (95\% CI: 10-16) were removed in the group that received open surgery, while 19 lymph nodes were removed (95\% CI: $14-24)$ in the laparoscopic surgery group ( $p=0.021)$. Adequate lymphadenectomy (removal of at least 12 lymph nodes) was achieved in $58.1 \%$ of the total cases, in $50.0 \%$ of the patients who received open surgery, and in $75 \%$ of those who received laparoscopic surgery. Non-elderly patients and those with an advanced disease stage were more likely to receive an adequate lymphadenectomy $(p=0.004$ and $p=0.035$, respectively). Conclusion: Disease stage and patient age were the factors that had the greatest influence on achieving an adequate lymphadenectomy. The type of surgery did not affect the number of lymph nodes removed.

\section{Correspondence:}

Vilson Leite Batista.

E-mail: vilson_leite@msn.com

Financial source: none

Conflicts of interest: none

Received for publication: 08/01/2015 Accepted for publication: 19/03/2015

\section{DESCRTORES - Cirurgia colorretal} Linfadenectomia. Cirurgia vídeo-assistida.
RESUMO - Racional: No tratamento cirúrgico do câncer colorretal, a linfadenectomia é considerada adequada quando pelo menos 12 linfonodos são removidos. Objetivo: Avaliar se a operação videolaparoscópica afeta positivamente as taxas de linfadenectomia adequada. Métodos: Estudo observacional foi realizado com pacientes submetidos à operação aberta ou videolaparoscópica para câncer colorretal entre 2008 e 2013. As seguintes variáveis foram coletadas: gênero, idade, localização do tumor, histologia, grau de diferenciação, estágio do tumor, número de linfonodos removidos, e número de nódulos linfáticos afetados pela doença. Resultados: Um total de 62 pacientes com câncer colorretal foram incluídos; 42 (67,7\%) receberam operação aberta e 20 (32,3\%) laparoscópica. Quanto à linfadenectomia, média de 13 nódulos linfáticos (95\% CI: 10-16) foram removidos no grupo que recebeu a operação aberta, enquanto 19 linfonodos foram removidos (IC 95\%: 14-24) no grupo laparoscópico $(p=0,021)$. Linfadenectomia adequada (remoção de, pelo menos, 12 nódulos linfáticos) foi obtida em $58,1 \%$ dos casos no total, em $50,0 \%$ dos pacientes que receberam a operação aberta, e em $75 \%$ dos que receberam a laparoscópica. Pacientes não idosos e aqueles com estágio avançado da doença eram mais propensos a receber linfadenectomia adequada $(p=0,004$ e $p=0,035$, respectivamente). Conclusão: $O$ estágio da doença e a idade do paciente foram os fatores que tiveram a maior influência sobre a realização de linfadenectomia adequada. $O$ tipo de procedimento cirúrgico não afetou o número de linfonodos removidos.

\section{INTRODUCTION}

I is estimated that 15,070 men and 17,530 women will be diagnosed with colon and rectal cancer in Brazil in 2014. According to the latest global estimate in 2012, colon and rectal cancer is the third most common type of cancer among men, with 746,000 new cases, and the second most common among women, with 614,000 new cases. More than $50 \%$ are observed in more developed regions. The geographic patterns are similar for both genders, with males having a higher incidence in most populations ${ }^{8}$. Surgery remains the most effective treatment for colorectal cancer disease, and the number of lymph nodes surgically removed is directly correlated with patient survival $3,7,11,14,16,17$.

The first videolaparoscopic colectomy was performed in 1991, and since then, several studies have compared videolaparoscopic and conventional surgery ${ }^{9}$. Reports of port-site metastasis following laparoscopic surgery for colorectal cancer were described in 1996, creating concerns regarding the use of this technique. After this, 
the technique was analyzed for a long period of time to assess its oncological safety ${ }^{1,20}$. After 10 years of studies, laparoscopic colectomy was accepted as an alternative surgery for colorectal cancer, ${ }^{2,12,13}$.

There is no consensus in the literature stating the minimum number of lymph nodes needed to accurately identify stage $\mathrm{N}$. The minimum number of lymph nodes reported was $>7,>9,>13,>20$, or $>30^{10}$. However, the National Comprehensive Cancer Network (NCCN), the College of American Pathologists, and the American Joint Committee on Cancer (AJCC) suggest a minimum of 12 lymph nodes to establish the $\mathrm{N}$ stage ${ }^{4,15}$. Stage II patients who had less than 12 lymph nodes removed are considered high risk and adjuvant chemotherapy should be considered ${ }^{6}$. Based on this information, a lymphadenectomy can be considered adequate when at least 12 lymph nodes are removed.

This study aims to evaluate whether videolaparoscopic surgery increases the number of lymph nodes removed compared to laparotomic surgery.

\section{METHODS}

An observational and analytical study was conducted with patients undergoing surgery for colorectal cancer in a university hospital between January 2008 and December 2013. Patients undergoing either videolaparoscopic or open surgery for colorectal cancer were included in the study. Patients were excluded from the study if they had a macroscopic residual tumor after surgery, secondary neoplasia, emergent procedures, if they underwent surgery with a palliative intent, or if they received neoadjuvant chemotherapy and/ or radiotherapy.

The data obtained from the patients' medical records included the following variables: gender, age, tumor site, classification of lesions (proximal: from the right colon to the splenic flexure; distal: from the splenic flexure to the end of the rectosigmoid transition zone; and rectum: rectal lesions), histology (adenocarcinoma or mucinous carcinoma), degree of differentiation, tumor stage $\left(7^{\text {th }}\right.$ edition of the AJCC staging system $)^{5}$, number of lymph nodes removed, and number of lymph nodes affected by the disease.

A positive outcome (adequate lymphadenectomy) was defined as the removal of at least 12 lymph nodes according to the histopathological report. For univariate and multivariate analyses, patients aged $\geq 65$ years old were classified as elderly and those aged $<65$ years old were classified as non-elderly. The tumors were classified according to their location into colon for proximal and distal tumors and rectum for others. Regarding differentiation, tumors were classified as differentiated when they were well-differentiated and undifferentiated when they were moderately or poorly differentiated. The stage was classified into initial for stages I and II and advanced for stage III.

The hospital's surgical and pathology teams did not change during the study period. The lymphadenectomy was performed according to the location of the tumor. For proximal tumors, a right hemicolectomy extended to the transverse colon, with the lymphadenectomy performed at the origin of the ileocolic, right colic, and middle colic arteries. For distal tumors, a left colectomy and sigmoidectomy was performed with the ligation of the inferior mesenteric artery and vein at their origins. For rectal tumors, an anterior rectal resection (for lesions in the middle and upper rectum) or abdominoperineal resection (for lesions in the lower rectum) was performed. In these patients, the lymphadenectomy was extended to the level of origin of the inferior mesenteric artery. Total mesorectal excision was performed in all patients with tumors of the middle and lower rectum. All procedures (laparoscopic and open approaches) were performed with a standardized medial-to-lateral approach.

The surgical specimens were fixed in $10 \%$ formalin. The lymph nodes were identified and isolated in the mesocolic/ mesorectal fat through visualization and palpation. A routine paraffin embedding procedure and histological staining with hematoxylin and eosin were performed. The histopathological analysis (microscopy) was performed by one resident from the pathology residency program and reviewed by one pathologist. Adenocarcinomas were classified as well differentiated, moderately differentiated, or poorly differentiated. Well differentiated adenocarcinomas exhibit the following characteristics: simple and complex glands with certain regularity; nuclei with uniform sizes and shapes, basal positioning and preserved polarity; and similarity with the adenomatous epithelium. Moderately differentiated adenocarcinomas exhibit the following characteristics: more irregular glands that are still easily identifiable; and nuclei that exhibit a loss of basal positioning and a decrease or loss of polarity. Finally, the poorly differentiated adenocarcinomas exhibit the following characteristics: highly irregular glands that are absent or difficult to identify; loss of nuclear polarity; nuclear pleomorphism; and potentially a solid pattern. The histological grade was assigned according to the poorly differentiated areas, regardless of size.

Descriptive analysis was performed using measures of central tendency for continuous variables and absolute and relative frequencies for categorical variables. The groups shown in Tables 1 and 2 were compared using Pearson's Chi-squared Test. Relative risk (RR) was used to evaluate the association between the independent variables and the outcome (adequacy of lymphadenectomy). To control for confounding variables and construct the final model, multiple logistic regression was performed using stepwise forward modeling. In all evaluations, 95\% confidence intervals were used to assess statistical significance. All calculations were performed using SPSS 20 software.

\section{RESULTS}

Between January 2008 and December 2013, a total of 62 patients with colorectal cancer were included in the study, with 42 (67.7\%) undergoing open colorectal surgery and 20 (32.3\%) laparoscopic surgery. The mean age of the sample was 63.2 years (SD 13.8) and the majority of patients were female (54.8\%). Table 1 shows the socio-demographic and clinical characteristics of the patients according to the type of surgery performed. The variables age, gender, tumor site, tumor type, tumor differentiation, staging, and lymph node status were not significantly different between the groups of patients undergoing open vs. laparoscopic surgery.

Adequate lymphadenectomy (removal of at least 12 lymph nodes) was achieved in $58.1 \%$ of the total cases evaluated, and in $50.0 \%$ of patients who underwent open surgery and $75 \%$ of patients who received laparoscopic surgery.

Table 2 presents the associations between patient characteristics and adequate lymphadenectomy. The variables gender, tumor site, tumor type, differentiation, and lymph node status had no significant influence on the adequacy of lymphadenectomy. Non-elderly patients and those with an advanced disease stage were significantly more likely to achieve an adequate lymphadenectomy $(p=0.004$ and $p=0.035$, respectively). The logistic regression model controlled for these variables. 
TABLE 1 - Characteristics of patients according to the type of surgery performed

\begin{tabular}{|c|c|c|c|c|}
\hline Variable & $\begin{array}{l}\text { Total } \\
(n=62)\end{array}$ & $\begin{array}{l}\text { Open Surgery } \\
\quad(n=42)\end{array}$ & $\begin{array}{l}\text { Video Surgery } \\
\qquad(n=20)\end{array}$ & P-value* \\
\hline Age [mean (SD)] & $\begin{array}{c}63.23 \\
(13.78)\end{array}$ & 64.31 (14.45) & 60.95 (12.29) & 0.374 \\
\hline \multicolumn{5}{|l|}{ Gender (\%) } \\
\hline Female & $\begin{array}{c}34 \\
(54.8 \%)\end{array}$ & 20 (47.6\%) & $14(66.7 \%)$ & 0.112 \\
\hline Male & $\begin{array}{c}28 \\
(45.2 \%)\end{array}$ & $22(52.4 \%)$ & $5(41.7 \%)$ & \\
\hline \multicolumn{5}{|l|}{ Tumor Site (\%) } \\
\hline Proximal & $\begin{array}{c}26 \\
(41.9 \%)\end{array}$ & 19 (45.2\%) & $07(35.0 \%)$ & 0.654 \\
\hline Distal & $\begin{array}{c}23 \\
(37.1 \%)\end{array}$ & 14 (33.3\%) & 09 (45.0\%) & \\
\hline Rectum & $\begin{array}{c}13 \\
(21.0 \%)\end{array}$ & 09 (21.5\%) & 04 (20.0\%) & \\
\hline \multicolumn{5}{|c|}{ Tumor Type (\%) } \\
\hline Adenocarcinoma & $\begin{array}{c}53 \\
(85.5 \%)\end{array}$ & 36 (85.7\%) & $17(85.0 \%)$ & 1.000 \\
\hline $\begin{array}{l}\text { Mucinous } \\
\text { carcinoma }\end{array}$ & $\begin{array}{c}09 \\
(14.5 \%)\end{array}$ & 06 (14.3\%) & 03 (15.0\%) & \\
\hline \multicolumn{5}{|l|}{$\begin{array}{c}\text { Tumor } \\
\text { differentiation } \\
\text { (\%) }\end{array}$} \\
\hline $\begin{array}{c}\text { Well } \\
\text { differentiated }\end{array}$ & $\begin{array}{c}11 \\
(17.7 \%)\end{array}$ & $6(14.3 \%)$ & 05 (25.0\%) & 0.480 \\
\hline $\begin{array}{c}\text { Moderately } \\
\text { differentiated }\end{array}$ & $\begin{array}{c}49 \\
(79.0 \%)\end{array}$ & 35 (83.3\%) & $14(70.0 \%)$ & \\
\hline $\begin{array}{c}\text { Poorly } \\
\text { differentiated }\end{array}$ & 02 (3.2\%) & $1(2.4 \%)$ & 01 (5.0\%) & \\
\hline \multicolumn{5}{|l|}{ Tumor stage (\%) } \\
\hline I & $\begin{array}{c}09 \\
(14.5 \%)\end{array}$ & 5 (11.9\%) & 04 (20.0\%) & 0.534 \\
\hline II & $\begin{array}{c}24 \\
(38.7 \%)\end{array}$ & 18 (42.9\%) & 06 (30.0\%) & \\
\hline III & $\begin{array}{c}29 \\
(46.8 \%)\end{array}$ & 19 (45.2\%) & $10(50.0 \%)$ & \\
\hline \multicolumn{5}{|l|}{$\begin{array}{l}\text { Lymph nodes } \\
\text { status }\end{array}$} \\
\hline Positive & $\begin{array}{c}28 \\
(45.2 \%)\end{array}$ & 19 (45.2\%) & 09 (45.0\%) & 1.000 \\
\hline Negative & $\begin{array}{c}34 \\
(54.8 \%)\end{array}$ & $23(54.8 \%)$ & $11(55.0 \%)$ & \\
\hline
\end{tabular}

$\mathrm{SD}=$ Standard Deviation; * Pearson's Chi-squared Test

Regarding lymphadenectomy, the number of lymph nodes removed was significantly different between the two surgical approaches. The mean number of lymph nodes removed in the group of patients who received open surgery was 13 (95\% CI: 10-16) while in the group who received laparoscopic surgery, 19 lymph nodes (95\% CI: 14-24) were removed ( $p=0.021$; Figure 1$)$.

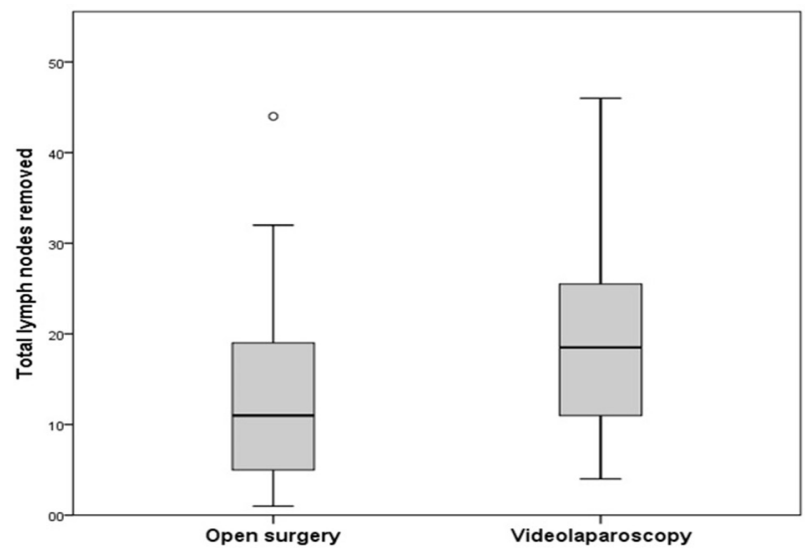

FIGURE 1 - Total lymph nodes removed for each surgical technique. The central line represents the median, the upper limit represents the third quartile, and the lower limit represents the first quartile. The value outside the limit is an outlier.
After adjusting for age and stage, patients undergoing laparoscopic surgery were 3.20 times more likely to receive an adequate lymphadenectomy compared to those undergoing open surgery (adjusted $\mathrm{OR}=3.20 ; 95 \% \mathrm{CI}$ : 0.86-11.90; $p$-value $=0.083$; Table 3).

TABLE 2 - Univariate analyses between patient characteristics and adequate lymphadenectomy (removal of at least 12 lymph nodes)

\begin{tabular}{|c|c|c|c|c|}
\hline \multirow[t]{2}{*}{ Variable } & \multicolumn{2}{|c|}{$\begin{array}{c}\text { Adequate } \\
\text { lymphadenectomy }\end{array}$} & \multirow[t]{2}{*}{ OR $(95 \% \mathrm{CI})$} & \multirow[t]{2}{*}{ p-value } \\
\hline & Yes (\%) & No (\%) & & \\
\hline \multicolumn{5}{|l|}{ Age } \\
\hline Non-elderly & $22(61.1 \%)$ & 06 (23.1\%) & $5.24(1.69-16.25)$ & 0.004 \\
\hline Elderly & $14(38.9 \%)$ & 20 (76.9\%) & Reference & \\
\hline \multicolumn{5}{|l|}{ Gender } \\
\hline Female & $19(52.8 \%)$ & $15(57.7 \%)$ & $1.22(0.44-3.37)$ & 0.701 \\
\hline Male & $17(47.2 \%)$ & $11(42.3 \%)$ & Reference & \\
\hline \multicolumn{5}{|l|}{ Tumor Site } \\
\hline Colon & 31 (86.1\%) & $18(69.2 \%)$ & $2.76(0.78-9.71)$ & 0.115 \\
\hline Rectum & 05 (13.9\%) & 08 (30.8\%) & Reference & \\
\hline \multicolumn{5}{|l|}{ Tumor Type } \\
\hline $\begin{array}{l}\text { Mucinous } \\
\text { carcinoma }\end{array}$ & $08(22.2 \%)$ & $01(3.8 \%)$ & $7.14(0.83-61.18)$ & 0.073 \\
\hline Adenocarcinoma & $28(77.8 \%)$ & 25 (96.2\%) & Ref & \\
\hline \multicolumn{5}{|c|}{$\begin{array}{l}\text { Tumor } \\
\text { Differentiation }\end{array}$} \\
\hline Differentiated & 06 (16.7\%) & 05 (19.2\%) & $0.84(0.23-3.12)$ & 0.794 \\
\hline Non-differentiated & $30(83.3 \%)$ & $21(80.8 \%)$ & Reference & \\
\hline \multicolumn{5}{|c|}{ Tumor stage } \\
\hline Advanced & $21(58.3 \%)$ & 08 (30.8\%) & 3.15 (1.09-9.13) & 0.035 \\
\hline Initial & 15 (41.7\%) & 18 (69.2\%) & Reference & \\
\hline \multicolumn{5}{|l|}{$\begin{array}{l}\text { Lymph nodes } \\
\text { status }\end{array}$} \\
\hline Positive & 20 (55.6\%) & 08 (30.8\%) & $2.81(0.97-8.13)$ & 0.056 \\
\hline Negative & 16 (44.4\%) & 18 (69.2\%) & Reference & \\
\hline
\end{tabular}

$\mathrm{OR}=$ Odds Ratio; $\mathrm{CI}=$ Confidence Interval

TABLE 3 - Unadjusted and adjusted associations between adequate lymphadenectomy (removal of at least 12 lymph nodes) and the type of surgery performed

\begin{tabular}{|c|c|c|c|c|}
\hline \multirow{2}{*}{ Variable } & \multicolumn{2}{|c|}{ Unadjusted OR } & \multicolumn{2}{|c|}{ Adjusted ORa } \\
\hline & OR $(95 \%$ CI) & $p$-value & OR $(95 \% \mathrm{CI})$ & $\mathrm{p}$-value \\
\hline Type of surgery & & & & \\
\hline Videolaparoscopy & $3.00(0.92-9.75)$ & 0.068 & $3.20(0.86-11.90)$ & 0.083 \\
\hline Open surgery & Reference & & Reference & \\
\hline
\end{tabular}

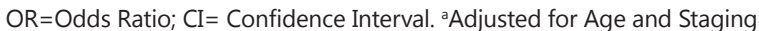

\section{DISCUSSION}

In colorectal disease, in addition to removing an adequate number of lymph nodes, lymphadenectomy should follow the following principles: lymph nodes at the origin of feeding vessels should be identified by pathological examination; clinically positive lymph nodes located outside the field of resection and considered suspicious should be biopsied or removed, if possible; and positive lymph nodes left behind indicate an incomplete resection (R2) ${ }^{15}$. In colorectal disease, staging, choice of adjuvant therapy, and patient survival are strongly influenced by an adequate lymphadenectomy $y^{5,7,16,18,19,21}$.

Previous studies have demonstrated that the number of lymph nodes removed is positively associated with increased survival16,17. A systematic review from 2007 that analyzed 17 studies of 61,371 patients and evaluated the association between the number of lymph nodes removed and the oncological results concluded that the number of lymph nodes evaluated after surgical resection was positively associated with the survival of patients with stage II and III colon cancer ${ }^{3}$. 
In the present study, the mean number of lymph nodes removed was greater for videolaparoscopic surgery than open surgery, though the mean was greater than 12 for both approaches. These data suggest that both approaches are oncologically safe. Some studies suggest that laparoscopic surgery has a small advantage over open lymphadenectomy. The wide use of video techniques and the improvement in equipments may be the reason for this change.

The pathologist performing the evaluation and the technical treatment of the specimen are important factors in lymph node count. The use of substances to prepare the specimens was associated with the total lymph node count and the number of positive lymph nodes identified ${ }^{18}$. The pathologist team did not change during the period of the present study and was the same for both groups; therefore, it is likely that this factor did not affect the results.

According to the literature, the number of lymph nodes removed varies by age, gender, tumor grade, and location of the tumor ${ }^{19}$. The disease stage and the patient's age were the factors that most influenced the adequacy of the lymphadenectomy in the present study. The influence of tumor stage is reasonable because more lymph nodes are identified as the disease advances. In contrast, the influence of age was an unexpected result. Age greater than 65 years was strongly associated with a failure to achieve adequate lymphadenectomy. One possible explanation is that this population is undertreated because of the elevated surgical risk due to comorbidities. Furthermore, the inflammatory response of an elderly patient may be associated with the number of identified lymph nodes. If confirmed in other studies, these data may indicate that the number of lymph nodes required for adequate staging may be different in elderly patients.

The results obtained in the present study cannot be considered conclusive. The limited number of patients analyzed and the retrospective nature of the analysis are limitations of the study.

\section{CONCLUSION}

Although the total number of lymph nodes removed was higher in the laparoscopic technique, there was no statistically significant difference between the approaches presented. Disease stage and patient age were the factors that had the greatest influence on achieving an adequate lymphadenectomy. The type of surgery did not affect the number of lymph nodes removed.

\section{REFERENCES}

1. Akle CA. Early parietal recurrence of adenocarcinoma of the colon after laparoscopic colectomy. Port site metastasis after laparascopic colorectal surgery for cure of malignancy. Br J Surg. 1996 Mar;83(3):427.

2. Campos FG, Valarini R. Evolution of laparoscopic colorectal surgery in Brazil: results of 4744 patients from the national registry. Surg Laparosc Endosc Percutan Tech. 2009 Jun;19(3):249-54.
3. Chang GJ, Rodriguez-Bigas MA, Skibber JM, Moyer VA. Lymph node evaluation and survival after curative resection of colon cancer: systematic review. J Natl Cancer Inst. 2007 Mar 21;99(6):433-41..

4. Compton CC, Fielding LP, Burgart LJ, Conley B, Cooper HS, Hamilton $\mathrm{SR}$, Hammond ME, Henson DE, Hutter RV, Nagle RB, Nielsen ML, Sargent DJ, Taylor CR, Welton M, Willett C.Prognostic factors in colorectal cancer. College of American Pathologists Consensus Statement 1999. Arch Pathol Lab Med. 2000 Jul;124(7):979-94.

5. Edge SB, Compton CC. The American Joint Committee on Cancer: the 7th edition of the AJCC cancer staging manual and the future of TNM. Ann Surg Oncol. 2010 Jun;17(6):1471-4..

6. Figueredo A, Coombes ME, Mukherjee S. Adjuvant therapy for completely resected stage II colon cancer. Cochrane Database Syst Rev. 2008 Jul 16;(3):CD005390.

7. Hashiguchi $Y$, Hase $K$, Ueno $H$, Mochizuki $H$, Kajiwara $Y$, Ichikura T, Yamamoto J. Prognostic significance of the number of lymph nodes examined in colon cancer surgery: clinical application beyond simple measurement. Ann Surg. 2010 May;251(5):872-81.

8. INCA - Instituto Nacional do Câncer Estimativa 2014: Incidência de Câncer no Brasil. Available at: http://www.inca.gov.br/ estimativa/2014/ (Accessed 19 August 2014), 2014.

9. Jacobs M, Verdeja JC, Goldstein HS. Minimally invasive colon resection (laparoscopic colectomy). Surg Laparosc Endosc. 1991 Sep;1(3):144-50.

10. Joseph NE, Sigurdson ER, Hanlon AL, Wang H, Mayer RJ, MacDonald JS, Catalano PJ, Haller DG. Accuracy of determining nodal negativity in colorectal cancer on the basis of the number of nodes retrieved on resection. Ann Surg Oncol. 2003 Apr;10(3):213-8.

11. Le Voyer TE, Sigurdson ER, Hanlon AL, Mayer RJ, Macdonald JS, Catalano PJ, Haller DG. Colon cancer survival is associated with increasing number of lymph nodes analyzed: a secondary survey of intergroup trial INT-0089. J Clin Oncol. 2003 Aug 1;21(15):2912-9.

12. Lee JK, Delaney CP, Lipman JM. Current state of the art in laparoscopic colorectal surgery for cancer: Update on the multicentric international trials. Ann Surg Innov Res. 2012 Jul 30;6(1):5.

13. Lourenco T, Murray A, Grant A, McKinley A, Krukowski Z, Vale L. Laparoscopic surgery for colorectal cancer: safe and effective? - A systematic review. Surg Endosc. 2008 May;22(5):1146-60..

14. Lykke J, Roikjaer O, Jess P; Danish Colorectal Cancer Group. The relation between lymph node status and survival in Stage I-III colon cancer: results from a prospective nationwide cohort study. Colorectal Dis. 2013 May;15(5):559-65.

15. National Comprehensive Cancer Center Network Clinical Pratice Guideline in Oncology (NCCN Guidelines): Colon Cancer. Version 3.2013 Available at: http://www.nccn.org (Accessed 8 August 2013). In: NCCN editor, 2013.

16. Onitilo AA, Stankowski RV, Engel JM, Doi SA. Adequate lymph node recovery improves survival in colorectal cancer patients. J Surg Oncol. 2013 Jun;107(8):828-34.

17. Parsons HM, Tuttle TM, Kuntz KM, Begun JW, McGovern PM, Virnig BA. Association between lymph node evaluation for colon cancer and node positivity over the past 20 years. JAMA. 2011 Sep 14;306(10):1089-97.

18. Rivadulla-Serrano MI, Martínez-Ramos D, Armengol-Carrasco M, Escrig-Sos J, Paiva-Coronel GA, Fortea-Sanchís C, Salvador-Sanchís J. Impact of the total number of harvested lymph nodes after colon cancer resections on survival in patients without involved lymph node. Rev Esp Enferm Dig. 2010 May;102(5):296-301.

19. Sarli L, Bader G, Iusco D, Salvemini C, Mauro DD, Mazzeo A, Regina G, Roncoroni L. Number of lymph nodes examined and prognosis of TNM stage II colorectal cancer. Eur J Cancer. 2005 Jan;41(2):272-9..

20. Taffinder NJ, Champault G. Port site metastases after laparoscopic colorectal surgery for cure of malignancy. Br J Surg. 1996 Jan;83(1):133.

21. Wright FC, Law CH, Berry S, Smith AJ. Clinically important aspects of lymph node assessment in colon cancer. J Surg Oncol. 2009 Mar 15;99(4):248-55. 